Here weather is the change a shadow makes in the shape on a wall, and the hours a depth in the colour of the stone,

a past that we commute to, old centres only the banks can afford.

Bus queues line the Cornmarket, bound for the outer estates.

The fare stage is in Old French.

\title{
3
}

Pitched into fields, on hillsides where the post-war tide left them, before the next high water.

Seven prefabs are still here to recall our origins.

The hill's first settlement. We walk to the shops at the Top. We wait at the roundabout where the bus turns.

Change becomes stationary. Silence made to be broken.

\section{John Cassidy on Roger Garfitt}

The hectorings which British poetry has sustained for fifteen years or more, on both sides of the Atlantic, seem to have had only a limited impact on poetic practice. There have been loud and public instructions about routes to be followed, but poetry has for the most part followed its own nose. Ambition, risk-taking and the ditching of burdensome traditions are admirable virtues, none the less enviable for the persistent salesmanship with which they have been recommended; they may indeed be requisites we cannot afford to be without.

What I suggest is that qualities like these are not so blatantly recognisable as some commentators would have us think, and that there are other excellences worthy of pursuit. The associated faults of overt ambition-posturings, rodomontade, the approach of the ludicrous-are no less inimical to poetry than debilitating gentility. A paradoxical form of daring is that 
which recognises the dangers and relies on skilful manoeuvring to adventure through them. Thus wariness, craft and persistence are the marks of the explorer, and his determination enables him to ignore the risk of being thought cold-footed.

The themes of Roger Garfitt's poetry include history, death, nature and society, which are bold enough in scope to guarantee his ambition. But there are no grand gestures in his approach, no modish exhibitionism. His lines often move, as in "Rosehill," as if feeling their way with very precise steps into the unknown. The line-spacing, the slight variations on a basic seven-syllable line, the directions to the reader's eye and ear, produce a series of stops and starts, of little confident runs, of reaching small certainties.

\author{
Their voices \\ as they rise have distance \\ in. \\ On the edge \\ of the moving city, they look over \\ houses their grandparents called \\ mushroom growth.
}

Larger matters are immanent. The light pressures of the past are present equally with the patterns of cloud shadows on the playground. History is always here, even though it fell behind us into the archaeological layers seven feet down. The "groundwork" is felt, as the existence of the past in place-names is felt, in a way unconscious and unbidden. For Garfitt continuity is a strong city, and language is a preservation-in Steiner's sense though not with Steiner's despair.

The direction in "Rosehill" is not towards the language of silence. The past is valued for the sense of scale it conveys, for the sharper realisation of the present and future, and the social observation in the latter part of the extract is a terse statement about the nature of change. We grow away from our past as we catch buses from the Cornmarket to the outer suburbs, but times coalesce as we pass the fare stage recalling the Norman Conquest, and the prefabricated houses marking the first post-1945 outposts of the spreading city, and reach the bus terminus which is its present frontier. The passage is rich in suggestion.

Roger Garfitt's main collection to date, West of Elm (Carcanet, 1974), offers a variety of moods and subjects and methods, but there is the same air of scrupulous hesitation that I detect in "Rosehill." There is a concern with wariness, with the constant possibility of disaster dropping from nowhere, as death drops onto the rabbit in "Out of a Clear Blue Sky"-a title which could cover much of Garfitt's field of vision. In that poem the sense of threat has been built up from the opening lines: the combine lumbers 
round the last decreasing area of uncut corn in which the rabbits are confined, and a line of men closes in and waits for them to break, drawing a noose "on the gap between the trapped and the wild." In other poems the menace is more sudden and more casual. "Remnants of fur / cancelled by a wheel" turn into anonymous marks on the road in the morning rush hour, "mysteries briefer than skidmarks." There is horror at witnessing the moment of impact when an animal is killed on the road, relief when what seemed to be "a thrush / splashed on the road" turned into a clump of grasses, when a squirrel, run over by a car, amazingly survived and "in three loops / was back in the pines." In such a world, he suggests early in his collection, "Instinct / has an eye on the silence, an ear for the dark."

"Steps," the presentation of an old man walking gingerly, "his body leaning to the stick," expresses perfectly this aspect of Garfitt's work. As the old man progresses, "his weight withheld from the footstep," he shows "the persistent flair for balance." "Steps" is a striking poem, and I extract from it lines which seem to apply outside itself to a recognisable Garfitt stance, to his characteristic watchfulness and perseverance.

West of Elm has a number of nicely observed accounts of the natural world, and there is a sense of the countryside as a place where people live and work. In fact the collection is more plainly concerned with concrete realities than are the poems printed in this symposium, which seem to show a greater distancing of the subject and a much more oblique approach. "Strix" is a lengthy account of the release of a tawny owl accidentally caught in netting inside a barn; there is an almost obsessive exactness in the description, a patient searching for the precise,

\title{
its open eyes
}

\author{
in the light \\ they are bruises of blue \\ bruised flints \\ liver blue
}

as the short lines insistently try to encompass the object.

More often Garfitt speaks of the natural scene as he observes it from his car, blurred by speed and consequently deceiving. There are several car poems, putting the poet in the position of a detached spectator of the world outside his enclosure, cut off once he "muffs the door shut."

Notable in these poems is a gift for the arresting phrase: the hitchhiker using "a sly elocution of the thumb," the heron which "shakes out his pac-a-mac of wings," and the morning with its "hanging landslide of rain." This facility is present again in the recent work. "Gardening in Avernus" has thyme which is "reptile over the dry rocks," and there is a night wind 
which "foxes the grass." But the choice of that verb "foxes," with its several associations, takes description a stage further than in the West of Elm poems. With the stealthiness there is puzzlement; the time-sequence-evening to night to late afternoon-is a shade disturbing, as the sense of smell translates the poet in a quick dissolve to a distant country and a distant time. Now contradictions are boldly juxtaposed; the dusk owl and the bats patrol under the noon blue and over trees without shadows, and we recognise what is happening before the confirming words, "I have come where the tenses / elide."

Distance, from the English garden to the Mediterranean dry rock, lizards and cedars, is obliterated, times are coalesced, and Avernus, the entrance to the Underworld, has been reached through "the common scent of earth." The coinciding inputs, from the imagination and from the senses, operate the "electronic gate" into a new sense of identity. This fusion of times, of myth and electronics, is convincingly done, though at the expense of some of Garfitt's previous sparkle. There is in this poem less of the element of verbal surprise which distinguishes West of Elm.

This preference is presumably a considered choice. In a poem he wrote to commemorate the death of Auden, Garfitt has a show of energetic wordplay which he clearly enjoys, and which is very different from the rather ascetic mood of "Gardening in Avernus." With a dazzling range of reference, to Auden's poems, to Shakespeare, to popular radio shows, to the Sagas, and with a dash of Auden's own logodaedaly, he has produced a kind of informative pastiche with something of the tone of "Funeral Blues." There is a swinging confidence about this performance, allowing the occasional slack line-“a whole set of assumptions died here"-and a jokiness"something is missing / something extra, Audenary"-which even this subject does not quite justify.

The variety in Garfitt's work is encouraging. The wit of "In Memoriam W. H. Auden" and of poems like "B Roads," the raising of description to an almost moral activity in "Strix," the searching after elusive significance in the two poems printed here, suggest an openness and a curiosity which are splendid attributes in a developing poet. Working within the strict syllabic measure of "Avernus," or in the more tentative movement of "Rosehill," Garfitt manages to pack his lines with considerable freightage. The obliquity and self-awareness of his more recent manner may prove to be a fruitful development from the immediacy of his earlier work. He has pursued the economy and sharpness of "Spring Greens," for example. I quote the entire poem:

Whiskers on the moss. Rust burns beneath the overflow. In the tenements, the damp is changing seasons. 


\section{And all the tins in Tesco's \\ sharpen their colours.}

The social awareness inheres in the perception. It is effortless, and this kind of ease is seen again in "Rosehill." "The fare stage is in Old French" is a neater piece of telescoping than the rather obvious "The hares meet / as they met before Enclosure" ("Hares Boxing").

Garfitt's poems arise from an initial perception, registered with its due weight, and this I admire. The implications are examined: today's life is tomorrow's history and is the archaeology of the day after that; or, there are objects and experiences to be savoured, however small, and they demand respect:

In midwinter's early dark

from a small tree by the church's wall

a flush of berries

met the sky's blue shrill

("Caught on Blue," the title poem of his first pamphlet)

With Roger Garfitt perception is primary, establishing the life of the senses which triggers the release of imagination. In "Animula" he settles for "the ache of mammal and clay," and it is a trustworthy starting-place. It will be instructive to see where his explorations take him next.

\section{Roger Garfitt Replies}

Auden speaks of two phases in a poet's development, one in which you are sure of yourself because you are able to judge the new work against the best of your old, the other in which you can only say, I don't know whether this is any good or not, but it's what I mean. In practice, I imagine, these phases recur and intersect. In some recent poems I have consciously worked from whatever ground I won in West of Elm: but with the two printed here I took my first steps onto terra infirma. John Cassidy's close and perceptive reading does much to reassure me that I've not been chasing a will o' the wisp.

Not many of us are likely to get as far as Auden did, but the risks he took with his own style from 1939 onwards, and the consequent broadening of his achievement almost to the time of his death, stand as pointers to the only way ahead. The alternative, which sadly is the course most English poets have followed since the War, is to achieve technical excellence very 
early, and then atrophy. As I first conceived it, "In Memoriam W. H. Auden" (published in Poetry Nation 4) was a kind of dual lament, an attempt to write for Auden in the spirit of MacNeice, but the poem's argument really became an appreciation of Auden's deepened humanity in

\section{leaving the bright coinage of his lyric style \\ like a crooked sixpence on a crooked stile.}

(Though I would argue, of course, as many would that in his later work the lyric has become integral to a much denser texture, and thereby more intense.)

I accept, indeed I share, Cassidy's view that the poems printed here lack the verbal impact of those in West of Elm. I do so without equanimity, but more equably than I could have a year or two back. Verbal power still matters to me-my first allegiance in poetry was to Hopkins, my second to Ted Hughes-but time and again in recent reading I have found my response to the totality of a poet's work outlasting my delight in individual lines. Two experiences in particular have become touchstones: one was to discover Brodsky, in poems like "A Letter in a Bottle," "A Halt in the Desert," and "Adieu, Mademoiselle Veronique," orchestrating levels of style and meaning until a moment of personal significance broadened into the reflection of his own times; the other has been to see Jon Silkin, in poems like "Killhope Wheel" and "Breaking Us," distilling concern into a lyric translucent in its simplicity yet, again, manifold in the implications it reflects:

Love, we are dust, owing rent.

To exploit another distinction Auden makes in The Dyer's Hand, perhaps one looks for an immediacy that can fuse primary and secondary imagination. Perhaps it is there that we could reforge the style of a unified sensibility. The instinctive forces and energies of the blood that drew me in West of Elm could not have entered, without loss, the largely secondary world of my recent work. The one image I have experienced as able to transmute without losing, for me, its primary power is that of light, which moves from "the sky's blue shrill" in Caught on Blue through "What lines the mirror of the fields of light?" in West of Elm to the last two lines of the final section of "Rosehill":

And for half or a minute we are as old as the light.

Accordingly, in that final section: 
Winter sunlight defines us, momentary hill figures, in negative on lit slopes:

we are a footstep's shadow; we are the echo of light.

As you turn to me, and in turning take my arm, the sun travels through our coats and forms unwoven matter on fibres of light

and here

this slight and linear dark where your shadow and mine cross.

Winter heat in the pavement. A pigeon suns on a roof.

And for half or a minute we are as old as the light.

I have brought the line back to a strict seven-syllable measure, and, I hope, to a more lyrical behaviour.

\section{Factory at Nightfall / John Cassidy}

You head north, from the way the smoke moves off your stack, lying back as if slipstreamed, a ship steaming full into the wind's teeth.

Steady though, brick steady, foursquare planted on the rolling land, trees splurging at the bow, grass whistling way out behind in a great wake.

All your windows, hundreds, blazing ports challenging the dull dusk, the cluttered ocean that you sit on. Travellers miles away absorb you, awestruck.

Even at a distance the unvarying growl of your bowels has a rare solidity. Something is under way, a drive with a known purpose, a kind of trust. 